удК 35.081 .73

\title{
ОСОБЛИВОСТІ ФОРМУВАННЯ І РЕАЛІЗАЦІЇ ПРОФЕСІОНАЛІЗМУ ПРАЦІВНИКІВ ОРГАНІВ ДЕРЖАВНОГО УПРАВЛІННЯ
}

\section{FEATURES OF FORMATION AND IMPLEMENTATION OF PROFESSIONALISM OF PUBLIC ADMINISTRATION EMPLOYEES}

\author{
Носань Наталія Сергіївна \\ кандидат історичних наук, доцент, \\ Черкаський національний університет імені Богдана Хмельницького \\ ORCID: https://orcid.org/ 0000-0002-4005-8333 \\ Московченко Тетяна Віталіївна \\ студентка, \\ Черкаський національний університет імені Богдана Хмельницького \\ ORCID: https://orcid.org/ 0000-0002-6725-5468 \\ Nosan Natalia, Moskovchenko Tetiana \\ Cherkassy National University named after Bohdan Khmelnytsky
}

\begin{abstract}
Робота присвячена визначенню особливостей формування та реалізації професіоналізму працівників органів державного управління. Визначено напрямками реорормування системи органів державної влади і управління: рефрормування системи професійної підготовки та реорганізація роботи кадрових служб органів державного управління. Досліджено особливості праці державних службовців. Проаналізовано ряд нормативних актів України в яких передбачені кваліфрікаційні вимогами до службовців, які займають державні посади державної служби. Досліджено основні складові професіоналізму державних службовців. Доведено необхідність оцінювання рівня професійної підготовки державних службовців. Досліджено методи оцінки професійної підготовки державних службовців, які не суперечать державним законам і іншим нормативним правовим актам України.
\end{abstract}

Ключові слова: працівники, професіоналізм, державний службовець, державна служба, державне управління.

Работа посвящена определению особенностей формирования и реализации профессионализма работников органов государственного управления. Определены направления реформирования системы органов государственной власти и управления: реформирование системы профессиональной подготовки и реорганизация работы кадровых служб органов государственного управления. Исследованы особенности труда государственных служащих. Проанализирован ряд нормативных актов Украины в которых предусмотрены квалисрикационные требования к служащим, которые занимают государственные должности государственной службы. Исследованы основные составляющие профессионализма государственных служащих. Доказана необходимость оценки уровня профессиональной подготовки государственных служащих. Исследованы методы оценки профессиональной подготовки государственных служащих, которые не противоречат государственным законам и другим нормативным правовым актам Украины.

Ключевые слова: работники, профессионализм, государственный служащий, государственная служба, государственное управление.

The formation of a professional civil service in Ukraine is one of the most pressing problems of the current period of socio-economic development of the country. The processes of deepening mutual ties between the state and civil society, the division of powers and the formation of a system of effective interaction of all branches of government requires a qualitatively different level of professional compliance of civil servants with the tasks facing them. The purpose of the study is to determine the features of the formation and implementation of professionalism of public administration employees. The paper identifies areas for reforming the system of public authorities and administration: reforming the system of vocational training and reorganization of personnel services of public administration. Peculiarities of work of civil servants are investigated. A number of normative acts of Ukraine are analyzed, which provide for qualification requirements for employees holding public positions in the civil service. The main 
components of professionalism of civil servants are studied. The necessity of assessing the level of professional training of civil servants is proved. The methods of assessment of professional training of civil servants, which do not contradict the state laws and other normative legal acts of Ukraine, are investigated. Conclusions: The practice of professional training of civil servants shows a relatively low efficiency of the system. The paper proposes two most important areas of improvement: reforming the system of vocational training and reorganization of the personnel services of public administration. The functional scheme of formation and improvement of the system of professional training of employees of public administration bodies allows to trace the interaction of two components: the system of formation of professionalism and its implementation in the process of official activity. It is proposed to reorganize the system of professional training taking into account the typology of civil service positions. The training system should be consistent with the ways in which trained personnel are used and their promotion plans. This requires reforming the principles and technology of working with civil servants.

Keywords: employees, professionalism, civil servant, civil service, public administration.

Постановка проблеми. Становлення профресійної державної служби в Україні є однією 3 найбільш нагальних проблем нинішнього періоду соціально-економічного розвитку країни. Процеси поглиблення взаємних зв'язків держави і громадянського суспільства, розподіл повноважень і фоормування системи ефективної взаємодії всіх гілок державної влади вимагає якісно іншого рівня професійної відповідності державних службовців завданням які перед ними стоять.

Рефрормування української державної служби проводиться на стадії реалізації в країні моделі правової держави, що вимагає фрункціонального освоєння і нормативноправового закріплення нових фоорм методів роботи, органів державного управління. Особливо актуальною стає необхідність професійного освоєння державними службовцями нових фрорм і методів роботи. 3 цією метою в країні розпочато здійснення ресрорми державної служби, яка спрямована на:

- профресійне і кваліфіковане виконання державними службовцями всіх рівнів і рангів вимог законодавства та реалізацію органами державної влади та управління прийнятих політичних рішень;

- огородження суспільства від несумлінності, упередженості і свавілля державних службовців, що зловживають службовим становищем, а також корупції.

Можливості реалізації зазначених цілей ресрормування державної служби в значній мірі залежать від рівня професіоналізму, а також наявності громадянських і моральних якостей, необхідних особам, які і виконують фрункції, покладені суспільством на державний апарат. В останні роки орахівцями з управління персоналом проведені серйозні і масштабні дослідження в галузі аналізу ситуації в органах державного управління, де зайнято понад один мільйон людей. Оцінки рівня професіоналізму державних службовців в процесі їх атестації свідчать про значні роз- біжності між вимогами і профресійними можливостями працівників. Для виявлення причин подібної невідповідності і необхідно досліджувати особливості фрормування і реалізації профресіоналізму працівників органів державного управління.

Аналіз останніх досліджень і публікацій. Методичні та прикладні проблеми державної служби, будучи в своїй основі міждисциплінарними, передбачають поєднання економічних, правових і соціологічних методів дослідження, знайшли своє відображення в роботах відомих українських та зарубіжних авторів. Серед них: Н. Артеменко, Г. Атаманчук, О. Воронько, Н. Гончарук, В. Кушлін, Н. Нижник, Г. Леліков, Р. Бетнер, Ж. Грімо, Л. Ерхард, Р. Піганьоль, Х. Хілл та ін.

Виділення невирішених раніше частин загальної проблеми. Вагоме місце в роботах, названих авторів відводиться методам і якості профресійної підготовки кадрів для органів державного управління. Разом 3 тим аналіз економічної літератури переконує в тому, що ряд питань, які відносяться до цієї ссрери наукових розробок, залишається недостатньо всебічно дослідженим.

Формулювання цілей статті. Метою дослідження $€$ визначення особливостей формування та реалізації профресіоналізму працівників органів державного управління.

Виклад основного матеріалу. Ссрормована в даний час в Україні система державного управління і державної служби не в повній мірі відповідають поставленим перед країною завданням. Назріла необхідність реформування системи органів державної влади і управління за 3-ма напрямками:

- перерозподіл відповідальності і повноважень між органами влади різних рівнів;

- адміністративна ресрорма, тобто зміна фрункцій і повноважень органів виконавчої влади;

- реформа організаційно-правових основ фрормування державної служби. 
Адміністративна ресрорма націлена на обмеження втручання держави в економічну діяльність суб'єктів підприємництва, виключення дублювання фрункцій і повноважень державних органів виконавчої влади, організаційний поділ фрункцій, що стосуються регулювання економічної діяльності, нагляду та контролю, управління державним майном і надання державою послуг громадянам та юридичним особам.

Головними напрямами реформування системи державної служби України визнані:

1) створення комплексної нормативно-правової основи регулювання державної служби;

2) розробка ефективних механізмів проведення кадрової політики;

3) вироблення заходів щодо вдосконалення оплати праці державних службовців; впровадження програми підготовки кадрів для державної служби України та професійного розвитку державних службовців.

У програмі реформування системи державної служби вводяться принципово нове поняття державної служби як механізм державного управління.

При здійсненні адміністративної ресрорми ключовим $€$ питання про фрункції державних органів виконавчої влади, діяльність яких спрямована на реалізацію як загальних, так і специорічних управлінських функцій.

Завдання, які стоять перед державними органами виконавчої влади диктують необхідність укомплектування апарату висококвалісрікованим персоналом, тобто вдосконалення системи підготовки та перепідготовки потрібного контингенту просресійних державних службовців.

Особливості праці державних службовців виражаються в:

- специфіку його правового регулювання;

- завдання, що вирішуються в процесі повсякденної діяльності;

- характер професійної діяльності;

- принципи організації і фрункціонування апарату управління.

Спеціальні норми трудового права регламентують трудові правовідносини державних службовців, що виникають у зв'язку з надходженням на державну службу, її проходженням і припиненням.

Крім загальних принципів трудового права, встановлюються додаткові вимоги і обмеження при вступі на державну службу - вони стосуються віку, рівня кваліфрікації, стану здоров'я, порядку укладення та умов трудового договору тощо. Мають місце обмеження, пов'язані з проходженням державної служби (неможливість займатися іншою оплачуваною діяльністю, крім педагогічної або наукової, займатися підприємницькою діяльністю, використовувати в неслужбових цілях державне майно і службову інфрормацію тощо). Додаткові вимоги встановлені і щодо припинення державної служби. Однак чинне законодавство потребує подальшого вдосконалення для досягнення більшої ефективності діяльності державних службовців щодо реалізації фрункції державного управління. Перш за все це стосується вимог до кваліфікації працівників апарату управління.

Ефрективність здійснених в країні реформ багато в чому залежить від знань, досвіду, просресійної підготовки, творчих здібностей і моральних якостей державних службовців.

Певним рядом нормативних актів України передбачені кваліфрікаційні вимогами до службовців, які займають державні посади державної служби:

- рівень професійної освіти з урахуванням групи і спеціалізації посад державної служби;

- стаж і досвід роботи за фахом;

- знання Конституції України, Законів України стосовно до виконання відповідних посадових обов'язків.

Спеціалізація державних посад державної служби встановлюється залежно від функціональних особливостей і особливостей предмета ведення відповідних державних органів.

Законодавчо регулюються, таким чином, рівень профресійної освіти, його просріль (спеціалізація), стаж і досвід роботи за фрахом. Так, для вищих і головних посад державної служби потрібна вища професійна освіта зі спеціалізацією державних посад державної служби або освіта.

Першоосновою організаційної структури будь-якого органу державного управління $\epsilon$ посада, яка окреслює межі реалізації професійних знань, навичок, досвіду і здібностей державного службовця.

Звісно ж, що в основі вимог до професійнокваліфікаційної підготовки працівників апарату управління повинна лежати модель посади державного службовця. На жаль питання аналізу та конструювання посад в державному апараті поки ще не знайшли широкого практичного застосування. Тим часом використання посадового моделювання, на наш погляд, дозволить вирішувати багато питань кадрового менеджменту, такі як:

- створення ефективного механізму відбору, підбору і розстановки кадрів;

- здійснення комплексної оцінки персоналу; 
- визначення нормативної чисельності державних службовців різних посадових груп тощо.

Моделі посад (або профресорами) повинні бути більш докладними і детальними ніж застосовувані нині квалісрікаційні характеристики, містити крім вимог до профресійних знань і досвіду роботи вимоги до спеціальних навичок, умінь, просресійно-значущих особистісних якостей.

Як свідчать результати вивчення даної проблеми розробка моделей державних посад ускладнена в зв'язку з відсутністю чіткого визначення та наукового опису змісту і особливостей різних адміністративно-управлінських видів діяльності. Тим часом розробка моделей державних посад могла б створити базу для формування більш досконалих програм підготовки кадрів за певними напрямами державної служби.

Актуальність проблеми, оцінки рівня профресійної підготовки постійно зростає у зв'язку із здійсненням адміністративного ресрормування влади і зростання потреби у відносно невеликому за чисельністю, але високопрофесійному корпусі державних службовців.

Оцінка рівня професійної підготовки повинна здійснюватися 3 метою визначення відповідності профресійних знань, умінь, навичок і досвіду роботи тим вимогам, які пред'являються до державних службовців певною посадою. При оцінці необхідно використовувати ознаки 3 незмінною значимістю для всіх категорій працівників. При цьому важливо мати на увазі, що рівень профресіоналізму складається 3:

- просресійної компетентності, тобто рівня і спеціалізації освіти, загальних і спеціальних професійних знань, отриманих у ВН3, на курсах тощо;

- досвіду роботи, який характеризується тривалістю загального трудового стажу, стажу роботи за конкретною спеціалізацією, стажу роботи на даній або аналогічній посаді, стажу роботи на керівних посадах тощо;

- періодичного підвищення квалісрікації, його виду та тривалості.

Оцінка рівня професійної підготовки повинна базуватися на регламентованих вимогах до кваліфрікації державних службовців, що містяться в організаційно-нормативних документах (кваліфікаційних характеристиках, профресійних стандартах тощо).

Для встановлення відповідності нормативних вимог і фрактичних показників (параметрів) профресіоналізму використовують різні методи. Правильність вибору методу (або їх сукупності) відповідає реалізації мети оцінки, визначає успіх (або невдачі) оцінки персоналу та отриманих результатів.

Необхідність оцінювати рівень професійної підготовки державних службовців, що виникає на різних стадіях їх службової діяльності (зарахування на службу, кваліфрікаційного і посадового зростання, кар'єрного просування тощо), диктує необхідність вибору 3 різноманіття існуючих методів оцінки саме таких, які дозволяють найбільш ефективно, тобто максимально повно, правильно і без значних матеріальних і тимчасових витрат, досягти мети проведення оцінки.

Концепцією ресрормування системи державної служби передбачається перехід від зарахування на державну службу в порядку призначення до прийому за конкурсом. При проведенні конкурсу повинні використовуватися методи оцінки які не суперечать державним законам і іншим нормативним правовим актам України (наприклад, анкетування, тестування, проведення групових дискусій, інтерв'ю тощо).

Анкетування рекомендується використовувати при наявності спеціально розроблених анкет (опитувальних листів), які передбачають дослідження і оцінку необхідних профресійних і особистісних якостей державних службовців.

Тестування ефрективно тоді, коли важливо визначити і оцінити необхідні якості працівника, встановити рівень розвитку цих якостей у вигляді конкретної величини (коефіцієнта або суми балів) за заздалегідь підготовленій шкалі оцінки.

Групові методи відбору (дискусії, ділові ігри, аналіз ситуацій) доцільно застосовувати при відборі претендента 3 декількох кандидатів. Їх використання передбачає наявність чітких критеріїв і способів виявлення переваг одних кандидатів перед іншими. Недоліком цих методів є можлива суб'єктивність оцінки.

За допомогою інтерв'ю можна оцінити широкий спектр якостей для роботи за пропонованою вакансії, але потрібні чіткі критерії, що обумовлені зі специфрікою тієї діяльності, для якої відбирається кандидат.

Визначення відповідності рівня профресійної підготовки державного службовця посади, на яку він претендує, проводиться при проведенні атестації. На жаль, поки не розроблено чітких і надійних критеріїв оцінки державних службовців, які гарантують якісне проведення атестації.

Також на нашу думку варто вказати на перспективність так званого матричного методу. Його сутність полягає в тому, що для кожної посади розробляється нормативна таблиця - 
матриця. У ній дається перелік просресійних і особистісних якостей, оптимальних по кожній конкретній посаді, і список осіб, які претендують на цю посаду. На перетині графр проставляються оцінки якостей працівників в балах. Так як значення окремих якостей неоднакове для роботи на конкретній посаді (одні головні, інші другорядні), то вводиться показник ваги. Вихідним критерієм оцінки ваги може бути одна з якостей, прийнята за одиницю.

Недоліком матричного методи $€$ велика трудомісткість попередньої роботи по складанню переліків фрункцій і якостей, необхідних для їх реалізації. Перевага цього методу полягає в тому, що він допомагає визначити рівень розвитку профресійних знань, навичок і умінь, а також напрями підвищення квалісрікації кожного працівника.

Висновки. Практика професійної підготовки державних службовців свідчить про відносно низьку ефрективність фрункціонування системи. В роботі пропонуються два найважливіші напрямки вдосконалення роботи: ресрормування системи профеесійної підготовки та реорганізація роботи кадрових служб органів державного управління. Функціональна схема фрормування і вдосконалення системи професійної підготовки працівників органів державного управління дозволяє простежити взаємодію двох складових: системи формування профресіоналізму та його реалізації в процесі службової діяльності.

Реорганізацію системи профресійної підготовки пропонується здійснювати з урахуванням типології посад державної служби. Система підготовки повинна бути узгоджена зі способами використання підготовлених кадрів і планами їх службового просування. Це вимагає рефрормування принципів та технології роботи з кадрами державних службовців.

Удосконалення срункціонування системи додаткової професійної підготовки передбачає: вдосконалення нормативно-правового забезпечення системи; створення ефективного організаційно-економічного механізму ії фрункціонування; підвищення якості навчання через механізм ліцензування і акредитації освітніх установ і програм; оновлення програм і методів навчання; проведення моніторингу стану профресійно-кваліфрікаційного потенціалу державних службовців.

\section{СПИСОК ВИКОРИСТАНИХ ДЖЕРЕЛ:}

1. Сурай І.Г. Професіоналізм та професійно-посадовий розвиток персоналу державної служби як складові державної кадрової політики. URL: http://academy.gov.ua/ej/ej6/txts/07sigdkp.htm

2. «Положення про систему профресійного навчання державних службовців, голів місцевих державних адміністрацій, їх перших заступників та заступників, посадових осіб місцевого самоврядування та депутатів місцевих рад» : Постанова Кабінету Міністрів України від 06 лютого 2019 року № 106.

3. Серьогін С.М., Бородін Є.І., Липовська Н.А. та ін. Рефрормування профресійного навчання державних службовців в Україні: проблеми та перспективи : монографрія. Київ : НАДУ, 2013. 112 с.

4. Толкованов В.В. Підвищення професійної компетентності державних службовців та посадових осіб органів місцевого самоврядування. Часопис Хмельницького університету управління та права. 2012. № 2. C. 23-30.

5. Максимович Ю.А. Проблеми підвищення кваліфікації державних службовців. URL: http://repository.hneu.edu.ua/ .../Максимович \%20

6. Ресрормування профресійного навчання державних службовців в Україні: проблеми та перспективи : монограсрія. URL: http://academy.gov.ua/NMKD/library_nadu/Monogr/78fbb398-860e-4902-a8dd-8c37711cd7d0.pdf

\section{REFERENCES:}

1. Suray I.H. Profesionalizm ta profesiyno-posadovyy rozvytok personalu derzhavnoyi sluzhby yak skladovi derzhavnoyi kadrovoyi polityky [Professionalism and professional development of civil service personnel as components of the state personnel policy]. URL: http://academy.gov.ua/ej/ej6/txts/07sigdkp.htm

2. «Polozhennya pro systemu profesiynoho navchannya derzhavnykh sluzhbovtsiv, holiv mistsevykh derzhavnykh administratsiy, yikh pershykh zastupnykiv ta zastupnykiv, posadovykh osib mistsevoho samovryaduvannya ta deputativ mistsevykh rad» [Regulations on the system of professional training of civil servants, heads of local state administrations, their first deputies and deputies, local government officials and deputies of local councils]: Postanova Kabinetu Ministriv Ukrayiny vid 06 lyutoho 2019 roku № 106.

3. Serohin S.M., Borodin YE.I., Lypovska N.A. ta in. (2013) Reformuvannya profesiynoho navchannya derzhavnykh sluzhbovtsiv $v$ Ukrayini: problemy ta perspektyvy: [monohrafiya] [Reforming the professional training of civil servants in Ukraine: problems and prospects: [monograph]. Kyiv: NADU. 
4. Tolkovanov V.V. (2012) Pidvyshchennya profesiynoyi kompetentnosti derzhavnykh sluzhbovtsiv ta posadovykh osib orhaniv mistsevoho samovryaduvannya [Improving the professional competence of civil servants and officials of local governments]. Chasopys Khmelnytskoho universytetu upravlinnya ta prava [Journal of Khmelnytsky University of Management and Law], no. 2.

5. Maksymovych Yu.A. Problemy pidvyshchennya kvalifikatsiyi derzhavnykh sluzhbovtsiv [Problems of advanced training of civil servants]. URL: http://repository.hneu.edu.ua/.../Maksymovych\%20

6. Reformuvannya profesiynoho navchannya derzhavnykh sluzhbovtsiv v Ukrayini: problemy ta perspektyvy: monohrafiya [Reforming the professional training of civil servants in Ukraine: problems and prospects: a monograph]. URL: http://academy.gov.ua/NMKD/library_nadu/Monogr/78fbb398-860e-4902-a8dd-8c37711cd7d0.pdf 